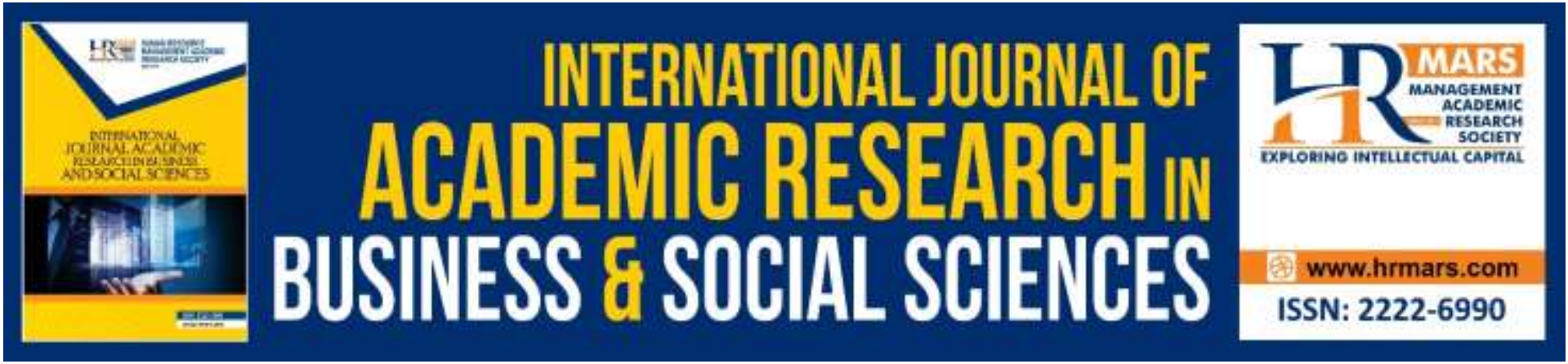

\title{
Sustaining Small Business Performance: Role of Entrepreneurial Orientation and Financial Access
}

Syamsuriana Sidek, Mohd Rosli Mohamad \& Wan Mohd Nazdrol Wan Mohd Nasir

To Link this Article: http://dx.doi.org/10.6007/IJARBSS/v9-i9/6270

DOI: $10.6007 /$ IJARBSS/v9-i9/6270

Received: 20 June 2019, Revised: 10 July 2019, Accepted: 23 August 2019

Published Online: 06 September 2019

In-Text Citation: (Sidek, Mohamad, \& Nasir, 2019)

To Cite this Article: Sidek, S., Mohamad, M. R., \& Nasir, W. M. N. W. M. (2019). Sustaining Small Business Performance: Role of Entrepreneurial Orientation and Financial Access. International Journal of Academic Research in Business and Social Sciences, 9(9), 66-80.

\section{Copyright: (C) 2019 The Author(s)}

Published by Human Resource Management Academic Research Society (www.hrmars.com)

This article is published under the Creative Commons Attribution (CC BY 4.0) license. Anyone may reproduce, distribute, translate and create derivative works of this article (for both commercial and non-commercial purposes), subject to full attribution to the original publication and authors. The full terms of this license may be seen at: http://creativecommons.org/licences/by/4.0/legalcode

\section{Vol. 9, No. 9, 2019, Pg. 66 - 80}

Full Terms \& Conditions of access and use can be found at http://hrmars.com/index.php/pages/detail/publication-ethics 


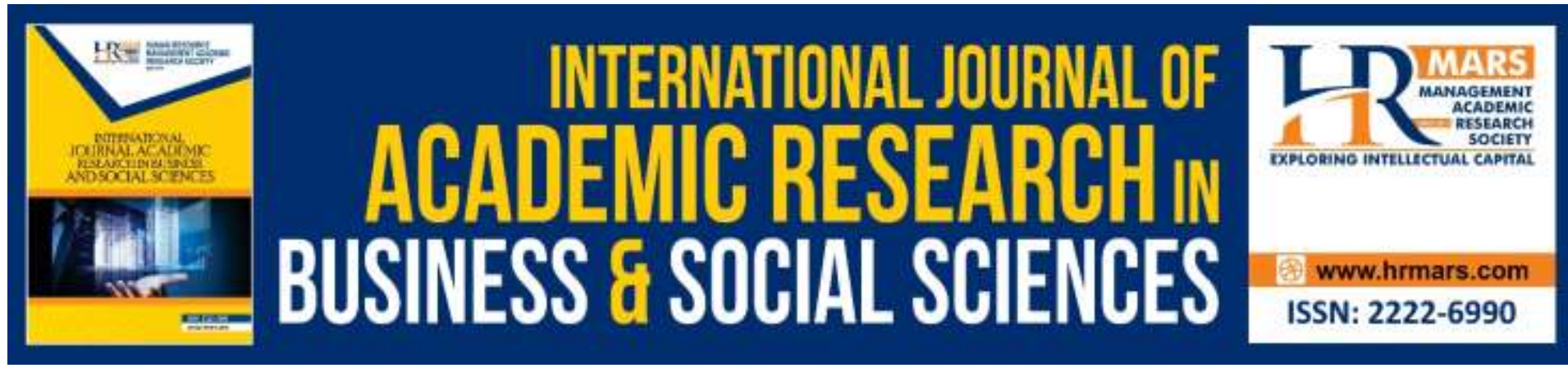

\title{
Sustaining Small Business Performance: Role of Entrepreneurial Orientation and Financial Access
}

\author{
Syamsuriana Sidek, Mohd Rosli Mohamad \& Wan Mohd \\ Nazdrol Wan Mohd Nasir \\ Faculty of Entrepreneurship and Business, Universiti Malaysia Kelantan, Malaysia \\ Email: suriana@umk.edu.my; mrosli@umk.edu.my; nazdrol@umk.edu.my
}

\begin{abstract}
Significance of small business performance to country growth has been acknowledged since many years ago. But peculiarly, high failure rate recorded derived from this sector. This issue sparked a heated debated among scholars lead to the focus on study of determinant factors of business performance including entrepreneurial orientation and financial access. Judging from this fundamental gap, this research aims to examine the relationship between entrepreneurial orientation and financial access on small business performance and mediating effects of financial access in between them. Resulting this, 280 small businesses in East Coast Malaysia were stratified selected to construct a structural model. This study concluded that entrepreneurial orientation was partially significant influence to small business performance, meanwhile; financial access was found partial mediating the relationship between entrepreneurial orientation and small business performance. Instead of consolidating current literatures, this study also provides early caution not only to government and policy makers but also to other authorities such as private bodies, NGOs, including small entrepreneurs on the important of entrepreneurial orientation and financial access towards development of small business.
\end{abstract}

Keywords: Entrepreneurial Orientation, Business Performance, Small Business, Financial Access, Mediating, Structural Model.

\section{Introduction}

Development of Small and Medium Enterprises (SMEs) together with small business in country has been wide-reaching known as contributors to the economic development many years before. This trend can be shown in the recorded statistics where they own higher than 80 per cent of global economic growth. Resulting this, utmost countries are recognized SMEs as the spinal of profitable expansion (SME Corporation Malaysia, 2019). Statistically, in emerging economies they contributed until $60 \%$ of total employment with $40 \%$ of Gross Domestic Product (GDP) and predicted to cater up 600 million employment opportunities in the forthcoming 15 years (The World Bank, 2019).

Adjudicating to their flourishing contributions, the sustainability of small business performance to ensure stability of economic in facing myriad challenges is becoming a critical 
agenda across the countries. Still, a large number of registered businesses depicted failure (Nassif, Ghobril, \& Silva, 2010). For instance, The Bureau of Labor Statistics (2018) in the US recorded $20 \%$ of registered small business be unsuccessful during their initial start-up and rose to $30 \%$ during the second year. This issue is not only arising in high-income countries but also occurring in upper-middle countries such as South Africa recorded $70 \%$ of business failed during second years of setup (BusinessTech, 2018) and China with $50 \%$ unsuccessful after five years of business operation (Zhang, 2013). No exception, Malaysia also facing this alarming situation whereby recorded business failure rate more than $80 \%$ for the last five years (Bernama, 2017).

Based on serious statistical business failure facts, the sustainability of small businesses performance becomes a critical issue need to be address by the present scholars. Nevertheless, this research topic currently still limited in their empirical studies, reliant on normative rules also weak in theory (Blackburn \& Jarvis, 2010; Leitch et al., 2010). Among these, Resource-based view (RBV) theory is the most cited theory related with performance (Barney, Wright \& Ketchen, 2001; Newbert, 2014). This theory described the organization that deploys strategic resources and capabilities were key factors to promise superior of their performance (e.g. Barney, 2001; Teece, 1982; Wernerfelt, 1984). Subsequently, the focus is needs for more empirically robust studies subject to a series of complex factors that determine sustainability of small business performance (Levie \& Lichtenstein, 2010) including entrepreneurial orientation (Awang, Ahmad, Asghar, \& Subari, 2010; Bolton \& Lane, 2012; Chang, 2015; Fatoki, 2012; Moreno \& Casillas, 2008; Preda, 2013) and financial access (Gill \& Biger, 2012; Mohammed \& Obeleagu-nzelibe, 2014; Xavier, Kelley, Kew, Herrington, \& Vorderwülbecke, 2013).

But, some prior researches and empirical studies found that relationship between entrepreneurial orientation and business performance was insignificant (see Khalil, Nejadhussein \& Fazel, 2013), openly assumed no direct impact of entrepreneurial orientation on business performance (Lumpkin \& Dess, 1996; Wiklund \& Shepherd, 2005). This raises the fundamental gap of this study to include mediating effects in this link. Some prior studies and empirical studies confirmed that entrepreneurial orientation would enhance access to finance (see Covin \& Lumpkin, 2011; Pandula, 2011; Ghimire \& Abo, 2013). In order to fulfil this research gap, this current study extended prior research works assumed that entrepreneurial orientation in small business may increase their chances for greater financial access and promise better performance. Thus, in attempting this assumption, this research underlined three main objectives of study which is: 1 ) to examine the relationship between entrepreneurial orientation and small business performance; 2 ) to determine the relationship between entrepreneurial orientation and financial access; 3 ) to determine the mediating effects of financial access in the relationship between entrepreneurial orientation and small business performance.

\section{Literature Review}

This section review prior studies by linking the relationship between each construct leads to formulation of the research hypotheses.

\section{Entrepreneurial Orientation and Business Performance}

Early idea of entrepreneurial orientation was presented by Miller (1983). Morris, Lewis, and Sexton (1994) defined entrepreneurial orientation as an individual or organizational 
preparedness to exploit new opportunities and responsible to change. Meanwhile, Walter, Auer, and Ritter (2006) denoted entrepreneurial orientation with readiness, processes and behaviour leads to new markets (or existing) goods or services via the existing (or new) ones. Many studies agreed that the significant of entrepreneurial orientation in business level is interconnected each other. For instance, Rauch and Frese (2009) pondered the variation of entrepreneurial orientation and business performance is $24 \%$. Likewise, the Fuentes-Fuentes, Bojica, and Ruiz-Arroyo (2015) depicted that entrepreneurial orientation is positively connected to financial and operational performance in the women-owned business. Moreover, Avlonitis and Salavou (2007) similar with Moreno and Casillas (2008) found that entrepreneurial organization influenced on profitability, development, innovation and performance in business. Henceforth, refereeing from these literatures, the first hypothesis can be written as:

H1: Entrepreneurial orientation is positively and significantly linked to small business performance.

However, since entrepreneurial orientation comes as multidimensional constructs (e.g.Covin \& Slevin, 1989; Kreiser, Marino, \& Weaver, 2002; Messeghem, 2003; Miller, 1983; Wiklund \& Shepherd, 2005), the sub-hypotheses can be written as follow:

H1a: Innovativeness is positively and significantly linked to small business performance.

H1b: Risk taking is positively and significantly linked to small business performance.

H1c: Aggressive competitiveness is positively and significantly linked to small business performance.

\section{Entrepreneurial Orientation and Financial Access}

The concept of financial access was continuously associated with Pecking Order Theory; highlighted that high propensities of the organization used internal financial sources instead of external financial sources in order to business financing (Myers \& Majluf, 1984). In most countries ranging from high-income to low-income economies, a growing number of small businesses require access to wide choice of financing sources (Hussain, Millman, \& Matlay, 2006). Generally, financial access can be deliberated as the capability of the business get advantage from credit or loan offered by financial intermediaries (The World Bank, 2019).

Adequate external financial access need to be combined with the internal elements in the business organization itself. As reminded by Miles, Arnold, and Thompson (2010), entrepreneurial orientation may possibly be a significant element in representing architectural of firm management. Similarly, entrepreneurial orientation can be a accelerate channel for the business to gain financial resources through better chances for them to access to external financing (Covin \& Lumpkin, 2011). Likewise, failures of financial access also due to incompetent owner in satisfactory financial suppliers (Smith \& Smith, 2007) bring the meaning lack of entrepreneurial orientation in the firm.

Based on these arguments, the current study expected that entrepreneurial orientation in small business may improve the opportunity for better external financial access. Accordingly, second hypothesis and sub-hypotheses can be formulated as:

H2: Entrepreneurial orientation is positively and significantly linked to external financial access.

H2a: Innovativeness is positively and significantly linked to external financial access. 
$\mathrm{H} 2 \mathrm{~b}$ : Risk taking is positively and significantly linked to external financial access.

$\mathrm{H} 2 \mathrm{c}$ : Aggressive competitiveness is positively and significantly linked to external financial access.

\section{Entrepreneurial Orientation and Business Performance: Mediating Role of Access to Finance}

This study highlighted that the role of entrepreneurial orientation in open up various chances for business to obtain access to external finances which finally contributed to the business performance. Based on study by Fatoki (2012), the business with entrepreneurial orientation is believed to have better access of debt capital since better off networking with the financial supplier. Accordingly, financial access offered assistance for business development as well as sound growth (Butler \& Cornaggia, 2009; Stam \& Garnsey, 2008).

Besides that,

Besides that, business that generated an effective strategic orientation such as entrepreneurial orientation could attract numerous external financial supports and promising revenues and profits (Cheng, loannou, \& Serafeim, 2014). Similarly, sufficient funds able to smooth up firm operations and being one of the crucial factors to the business growth (Isern et al., 2009; Hussain et al., 2006) since many decades ago.

Further, business organization with entrepreneurial talents may bring up more opportunities to external financial resources accessing (Mohammed \& Obeleagu-nzelibe, 2014). Whereas, external finance access particularly for small businesses not only can sustain a stable economic environments via encouraging innovation, macroeconomic elasticity and GDP growth in developing countries (Bouri et al., 2011), but also promote a sound of business operations and productions as refer to many earlier works (see Frank, Kessler, \& Fink, 2010; Wiklund \& Shepherd, 2005; Zampetakis et al., 2011).

Consecutively, this study assumed that an effective entrepreneurial orientation perhaps a good predictor of small business to external financial access, meanwhile, sufficient financial access would improve performance of existing business. Hereafter, the third hypotheses can be derived as:

H3: The relationship between entrepreneurial orientation and small business performance is mediated by financial access.

H3a: The relationship between innovativeness and small business performance is mediated by financial access.

H3b: The relationship between risk taking and small business performance is mediated by financial access.

H3c: The relationship between aggressive competitiveness and small business performance is mediated by financial access.

\section{Methodology}

This study employed primary data derived from survey of face-to-face and personally administered. This strategy would help the researchers to cater the issues of biasness, accuracy, homogeneous and goodness of the data obtained (Sekaran \& Bougie, 2013). In order to start the survey, the study developed a set of questionnaire signified into dual languages: English and Malay comprised of four main parts. 
Part $A$ is personal details of the sample comprised of general information of the respondent. Meanwhile, Part B is business performance acts as dependent variable of the study contained several items improved from Ar and Baki (2011), Gathenya et al. (2011) and Wei-Loon (2013). The items are sales (BP1), market share (BP2), customer satisfaction (BP3), product quality (BP4), profitability level (BP5), production level (BP6), number of employees (BP7), number of new customer (BP8) and income level (BP9) measured via five-points of Likert scale. Moreover, Part $C$ is entrepreneurial orientation as independent variable represented into three dimensions namely: innovativeness (INNO), risk taking (RISK) and aggressive competitiveness (AC) adapted from Bolton and Lane (2012), Lan and Wu (2010) and Wiklund and Shepherd (2005). Furthermore, this construct are treated as first order construct and measured by using five-points of Likert scale by which means each dimension represented by five items. Besides that, Part $D$ is financial access plays a role as mediating variable indicated by nine items from several past studies for instance Fatoki (2012), Mason, Floreani, Miani, Beltrame, and Cappelletto (2015) and Zampetakis et al. (2011) used Likert scale measurement symbolized by $1=$ no access, $2=$ irregular, $3=$ medium access, $4=$ regular access and $5=$ highly regular access. Additionally, financial access construct was treated as composite scale which means all the items are combined into a single observed construct with the purpose of better the consistency of the measurement and further accurately the anticipated responses (Hair et al., 2014).

Besides that, the sample was proportionate stratified randomly selected into two main strata: state and sector. Initially, the population was divided into strata of Kelantan, Terengganu and Pahang and once again they were divided into strata of sector such as services, manufacturing, construction, agriculture, mining and quarrying. Subsequently, the researchers download the sampling frame from SME Corporation Malaysia. At this time, all the respondents were randomly selected. All the collected questionnaires went through the screening process. Lastly, this study concluded that 280 sample enough to be used for AmosSEM technique.

\section{Procedures for Data Analysis}

\section{Confirmatory Factor Analysis (CFA)}

This study follow Prajogo (2007) whereby opts to separate the measurement model and the structural model. The CFA process begins via checking the factorial structure of each item (Alegre et al., 2006) in measurement model. The items with lower than 0.60 considered as low loading must be first dropped by the study (Mueller \& Hancockang, 2010). The similar process need to be done until the study achieved the goodness-of-fit by containing at least one index from each category of absolute fit, incremental fit and parsimonious fit (Hair et al., 2014). Hence, in order to reach the required indices, item BP2, BP4, BP7, INNO1, RISK2, AC3, and AC5 were dropped by the study to achieve measurement model fit. This resulted to: $X^{2}=$ 1673.611, $d f=612, X^{2} / d f=2.469, N F I=0.859, T L I=0.909, C F I=0.920$ and $R M S E A=0.068$.

\section{Validity, Reliability and Normality Assessment}

This study proceeds to the assessment of validity, reliability and normality after the measurement model fit. Convergent validity assessment is fulfilled if AVE values for constructs more than 0.50 as recommended by Mueller and Hancock (2010). Equally, discriminant validity for constructs is achieved when the square root of AVE depicted higher than the values of correlation between particular construct (Hair et al., 2014; Lu, Lai, \& Cheng, 
2006). Furthermore, internal reliability is judging based on Cronbach's Alpha value higher than 0.70 (Chang et al., 2007; Hair et al., 2014). Also, construct reliability (CR) for constructs definitely achieved as suggested by the rule of thumb upper than 0.60 (Hair et al., 2014). Last but not least, normality distribution of the data was accepted since the skewness portrayed below than 1.5 and CR is lower than 8.0 (Hair et al., 2014; Zainudin, 2015).

For the mentions assessment, this research has fulfilled the entire test adequate to further analysis. To strengthen, 280 sample of this study also sufficient to satisfy the assumption of using SEM analysis (Hair et al., 2014; Sekaran \& Bougie, 2013).

\section{Structural Model and Hypotheses Testing}

The structural model was developed after the measurement model completed goodness-of-fit in CFA procedure and assessment of validity, reliability as well normality was verified. Consequently, the results of testing $\mathrm{H} 1$ to $\mathrm{H} 2$ were concise as in Table 1.

Table 1: Hypotheses testing

\begin{tabular}{|c|c|c|c|c|c|c|}
\hline \multirow{2}{*}{$\begin{array}{c}\text { Hypothesis } \\
\text { H1a }\end{array}$} & \multicolumn{3}{|c|}{ Structural Path } & \multirow{2}{*}{$\begin{array}{c}\begin{array}{c}\text { Standardized } \\
\text { Estimate }\end{array} \\
0.127\end{array}$} & \multirow{2}{*}{$\begin{array}{c}\begin{array}{c}\text { P- } \\
\text { value }\end{array} \\
0.041\end{array}$} & \multirow{2}{*}{$\begin{array}{c}\text { Result } \\
\text { Significant }\end{array}$} \\
\hline & $\begin{array}{l}\text { Business } \\
\text { Performance }\end{array}$ & $\begin{array}{l}<- \\
--\end{array}$ & Innovativeness & & & \\
\hline $\mathrm{H} 1 \mathrm{~b}$ & $\begin{array}{l}\text { Business } \\
\text { Performance }\end{array}$ & $\begin{array}{l}<- \\
--\end{array}$ & Risk Taking & 0.398 & 0.001 & Significant \\
\hline $\mathrm{H} 1 \mathrm{c}$ & $\begin{array}{l}\text { Business } \\
\text { Performance }\end{array}$ & $\begin{array}{l}<- \\
--\end{array}$ & $\begin{array}{l}\text { Aggressive } \\
\text { Competitiveness }\end{array}$ & 0.058 & 0.047 & Significant \\
\hline $\mathrm{H} 2 \mathrm{a}$ & $\begin{array}{l}\text { Financial } \\
\text { Access }\end{array}$ & $\begin{array}{l}<- \\
--\end{array}$ & Innovativeness & 2.307 & 0.001 & Significant \\
\hline $\mathrm{H} 2 \mathrm{~b}$ & $\begin{array}{l}\text { Financial } \\
\text { Access }\end{array}$ & $\begin{array}{l}<- \\
--\end{array}$ & Risk Taking & 2.587 & 0.010 & Significant \\
\hline $\mathrm{H} 2 \mathrm{c}$ & $\begin{array}{l}\text { Financial } \\
\text { Access }\end{array}$ & & $\begin{array}{l}\text { Aggressive } \\
\text { Competitiveness }\end{array}$ & 1.091 & 0.611 & $\begin{array}{c}\text { Not } \\
\text { Significant }\end{array}$ \\
\hline
\end{tabular}

Note: 1) Highlighted row means hypothesis is supported by the study.

Source: Based on AMOS output developed for this study.

Overall, $\mathrm{H} 1$ is supported by the study since all dimensions of entrepreneurial orientation (innovativeness, risk taking and aggressive competitiveness) had significant relationship with small business performance. In details, $\mathrm{H} 1 \mathrm{a}$ is innovativeness $(r=0.127, p<$ $0.05)$; $\mathrm{H} 1 \mathrm{~b}$ is risk taking ( $r=0.398, p<0.001)$; and $\mathrm{H} 1 \mathrm{c}$ is aggressive competitiveness $(r=0.058$, $p<0.05)$ was significantly positive linked to small business performance. Less similarly, this research strongly supported $\mathrm{H} 2$ where not all dimensions of entrepreneurial orientation showed significant results. Only innovativeness $(\mathrm{H} 2 \mathrm{a})$ and risk taking $(\mathrm{H} 2 \mathrm{~b})$ dimension was significant, while, aggressive competitiveness $(\mathrm{H} 2 \mathrm{c})$ dimension was insignificant. In particular, innovativeness $(r=2.307, p<0.05)$ and risk taking $(r=2.587, p<0.05)$ was significantly positive linked to external financial access.

Otherwise, this research follows the guideline suggested by Baron and Kenny (1986) and Hair et al. (2014) to test mediating effect as formulated in H3 via comparing value of 
indirect path should be higher than value of direct path in the structural model. The details procedures are depicted in Table 2.

Table 2: Mediation test procedures

\begin{tabular}{|c|c|c|c|c|}
\hline Construct & $\begin{array}{l}\text { Standardized } \\
\text { Estimate }\end{array}$ & $\begin{array}{c}\text { P- } \\
\text { Value }\end{array}$ & Result & Decision \\
\hline $\begin{array}{l}\text { Innovativeness (INNO) } \\
\text { Direct effect: } \\
\text { INNO } \rightarrow \text { BP } \\
\text { Indirect effect: } \\
\text { INNO } \rightarrow \text { FA } \\
\text { FA } \rightarrow \text { BP } \\
\text { Total Indirect effect } \\
2.307 \times 0.219=0.505\end{array}$ & $\begin{array}{l}0.127 \\
2.307 \\
0.219 \\
0.505\end{array}$ & $\begin{array}{l}0.001 \\
0.020\end{array}$ & $\begin{array}{l}\text { Significant } \\
\text { Significant } \\
\text { Significant }\end{array}$ & $\begin{array}{c}\text { Partial } \\
\text { Mediation } \\
\text { Indirect effect > } \\
\text { direct effect = } \\
0.505>0.127\end{array}$ \\
\hline $\begin{array}{l}\text { Risk Taking (RISK) } \\
\text { Direct effect: } \\
\text { RISK } \rightarrow \mathrm{BP} \\
\text { Indirect effect: } \\
\text { RISK } \rightarrow \text { FA } \\
\text { FA } \rightarrow \text { BP } \\
\text { Total Indirect effect } \\
2.587 \times 0.219=0.567\end{array}$ & $\begin{array}{l}2.587 \\
0.219 \\
0.567\end{array}$ & $\begin{array}{l}0.001 \\
0.010 \\
0.020\end{array}$ & $\begin{array}{l}\text { Significant } \\
\text { Significant } \\
\text { Significant }\end{array}$ & $\begin{array}{c}\text { Partial } \\
\text { Mediation } \\
\text { Indirect effect > } \\
\text { direct effect = } \\
0.567>0.398\end{array}$ \\
\hline $\begin{array}{l}\text { Aggressive Competitiveness } \\
\text { (AC) } \\
\text { Direct effect: } \\
\mathrm{AC} \rightarrow \mathrm{BP} \\
\text { Indirect effect: } \\
\mathrm{AC} \rightarrow \mathrm{FA} \\
\mathrm{FA} \rightarrow \mathrm{BP} \\
\text { Total Indirect effect } \\
1.091 \times 0.219=0.239\end{array}$ & $\begin{array}{l}1.091 \\
0.219 \\
0.239\end{array}$ & $\begin{array}{l}0.047 \\
0.611 \\
0.020\end{array}$ & $\begin{array}{l}\text { Significant } \\
\quad \text { Not } \\
\text { Significant } \\
\text { Significant }\end{array}$ & $\begin{array}{l}\text { Path of } A C \text { to } F A \\
\text { is not significant }\end{array}$ \\
\hline
\end{tabular}

Note: $\mathrm{BP}=$ Small Business Performance; FA= Financial Access.

Source: Based on AMOS output developed for this study.

According to Table 2, this study found that the relationship between entrepreneurial orientation and small business performance is partially mediated by financial access. In particulars, only two out of three sub-hypotheses ( $\mathrm{H} 3 \mathrm{a}$ and $\mathrm{H} 3 \mathrm{~b}$ ) were supported by the study, meanwhile, $\mathrm{H} 3 \mathrm{c}$ is not supported since none mediating effects among path of aggressive competitiveness, financial access and small business performance. Specifically, in testing $\mathrm{H} 3 \mathrm{a}$, the value of indirect effect is higher than value of direct effect $(0.505>0.127)$ concluded to partial mediation since the direct effect is still significant. Similarly, in testing $H 3 b$, the value of indirect effect is more than value of direct effect $(0.567>0.398)$ leads to decision of partial 
mediation due to the direct effect is still significant. However, contradict in testing H3c; path of aggressive competitiveness and financial access is not significant which unsatisfactory requirement of the procedures in determine the mediating effect.

\section{Key Findings and Discussions}

The summary of 280 respondents of survey was portrayed as in Table 3. Based on the mentioned table, it could be concluded that majority of the respondents are male entrepreneurs (62.5\%), where majority of them were come from middle-age group ranged between 31 and 50 years old. Furthermore, in term of level of education, over half of respondents had completed form 1 to form 5 which is 54.6 percent, where only one per cent revealed that non-schooling, school dropout or owned foreign educational certificated.

As predictable, over $70 \%$ of survey sample were operating the services sector $(72.5 \%)$ by the meaning of offering restaurant, wholesale business, laundry, retail business, storage, accommodation, communication, beauty center, workshop, professional, stitches and transportation. Besides that, referring to active business period, most of the companies were operating between 3 and 10 years. Further, according to Business Life Cycle theory as introduced by Churchill and Lewis (1983), this study concluded that majority of the businesses are in growth stage. Perhaps the main scope of this research is small business; more than 75 percent of them owned Sole proprietorship business (76.1\%). 
Table 3: Details of sample

\begin{tabular}{|c|c|c|c|}
\hline Variables & & $\begin{array}{c}\text { Frequency } \\
(n=280)\end{array}$ & $\begin{array}{c}\text { Percentage } \\
(100.0 \%) \\
\end{array}$ \\
\hline \multirow[t]{2}{*}{ Gender } & Male & 175 & 62.5 \\
\hline & Female & 105 & 37.5 \\
\hline \multirow[t]{5}{*}{ Age (years old) } & $21-30$ & 36 & 12.9 \\
\hline & $31-40$ & 89 & 31.8 \\
\hline & $41-50$ & 95 & 33.9 \\
\hline & $51-60$ & 51 & 18.2 \\
\hline & $>60$ & 9 & 3.2 \\
\hline \multirow[t]{5}{*}{ Educational Level } & Primary school & 1 & 0.4 \\
\hline & Secondary school & 153 & 54.6 \\
\hline & Pre University & 85 & 30.4 \\
\hline & Tertiary & 38 & 13.6 \\
\hline & *Others & 3 & 1.0 \\
\hline \multirow[t]{4}{*}{ Business Category } & Services & 203 & 72.5 \\
\hline & Manufacturing & 53 & 18.9 \\
\hline & Construction & 11 & 3.9 \\
\hline & Agriculture & 13 & 4.6 \\
\hline Business Establishment & $3-6$ & 89 & 31.8 \\
\hline \multirow[t]{2}{*}{ (years) } & $7-10$ & 88 & 31.4 \\
\hline & $>10$ & 103 & 36.8 \\
\hline \multirow[t]{3}{*}{ Business Entity } & Sole proprietorship & 213 & 76.1 \\
\hline & Partnership & 40 & 14.3 \\
\hline & Private limited (Sdn. Bhd.) & 27 & 9.6 \\
\hline
\end{tabular}

Note: 1$)^{*}$ Others mean non-schooling or held foreign educational; 2 ) Sdn. Bhd. = Sendirian Berhad

Source: Based on survey output developed for this study.

The main findings of this study found that entrepreneurial orientation was significantly positive related to small business performance since all dimensions of entrepreneurial orientation were significant in line with many past works (see Awang et al., 2010; Esteve, Peinoda, \& Peinado, 2009; Lumpkin \& Dess, 1996; Roxas, 2009; Wiklund \& Shepherd, 2003) since starting of entrepreneurial orientation concept established by Miller (1983). As forecasted, entrepreneurial orientation as a strategic capability in the small firm was strongly positively and significantly related to external financial access supported by various earlier scholars for instances Covin and Lumpkin (2011), Hussain, Millman, and Matlay (2006), Miles, Arnold, and Thompson (2010) and Smith and Smith (2007).

Besides that, consistent with RBV theory as underpinning theory, this study connected the mediating role of external financial access in the relationship between entrepreneurial orientation and small business performance. But, nevertheless, this current study confirmed that external financial access has given not much impact on the relationship between entrepreneurial orientation and small business performance. Consequently, this research partially aligned with the many past studies such as Fatoki (2012), Ibrahim and Shariff (2015), Ogunsiji and Ladanu (2010), Wiklund and Shepherd (2005) and Zampetakis et al. (2011). 
Though that, Wiklund and Shepherd (2005) reminded that dissimilar findings in all probability to the contrast of the result pattern leads to entrepreneurial orientation studies different viewpoints (Frank, Kess, \& Fink, 2010). Also, Verwaal, Bruining, Wright, Manigart, and Lockett (2010) had mentioned that small business have less chances to external financial access compared to medium and large firm.

\section{Conclusion and Future Research}

The findings highlighted that risk taking was positively significant influence to small business performance, while, remaining two dimensions; innovativeness and aggressive competitiveness insignificantly related. Moreover, this research explained that financial access and small business performance has positive and significant relationship in line with numerous existing scholars. Extendedly, the result displayed that the relationship between entrepreneurial orientation and small business performance was partially mediated by financial access. This research concluded that entrepreneurial orientation in organization would increase the chance of small business to have better external financial access which finally promises to superior performance.

Theoretically, this nature of study contributes to provide understanding of how firms outperform is a fundamental concern of the RBV theory. Consequently, this research contributes to the body of knowledge by testing indirect relationship of entrepreneurial orientation, access to finance and business performance. Furthermore, empirically, this study extends current knowledge on entrepreneurial orientation by determining how access to finance mediates the relationship between entrepreneurial orientation and business performance. This study also contributes to the current literature and empirical findings in respective fields. In addition, practically this study also provides early caution not only to government and policy makers but also to other authorities such as private bodies, NGOs, including small entrepreneurs on the important of entrepreneurial orientation and financial access towards development of small business.

Aside from glowing contribution of the study, future research possibly could improve this research via added other factors since there are many internal or external factors determine performance. Besides that, upcoming researchers could employ the study framework into qualitative approach for the reason that this approach might offer sufficient standpoints advances to this study. Last but not least, this study also may enhance the scope of the study to SMEs since this study only limited to small business sample, where wider scope could increase the results generalization.

\section{References}

Alegre, J., Lapiedra, R., \& Chiva, R. (2006). A measurement scale for product innovation performance. European Journal of Innovation Management, 9 (4), 333-346.

Ar, I. M., \& Baki, B. (2011). Antecedents and performance impacts of product versus process innovation: empirical evidence from SMEs located in Turkish science and technology parks. European Journal of Innovation Management, 14 (2), 172-206.

Avlonitis, G. J., \& Salavou, H. E. (2007). Entrepreneurial orientation of SMEs, product innovativeness, and performance. Journal of Business Research, 60, 566-575.

Awang, A., Ahmad, Z. A, Asghar, A. R. S., \& Subari, K. A. (2010). Entrepreneurial orientation among Bumiputera Small and Medium Agro-Based Enterprises (BSMAEs) in West 
Malaysia: Policy implication in Malaysia. International Journal of Business and Management, 5(5), 13- 143.

Barney, J. B. (2001). Resource-based theories of competitive advantage: A ten-year retrospective on the resource-based view. Journal of Management, 27 (6), 643-650.

Barney, J., Wright, M., \& Ketchen, Jr. D. J. (2001). The resource-based view of the firm: Ten years after 1991. Journal of Management, 27 (6), 625-641.

Baron, R. M., \& Kenny, D. A. (1986). The moderator-mediator variable distinction in social psychological research: conceptual, strategic, and statistical considerations. Journal of Personality and Social Psychology, 51 (6), 1173-1182.

Bernama. (2017, March 30). Rahim: Failure rate among Bumi entrepreneurs still high. Retrieved

from: $\quad$ http://www.freemalaysiatoday.com/category/nation/2017/03/30/rahimfailure-rate-among-bumi-entrepreneurs-still-high/

Blackburn, R., \& Jarvis, R. (2010). The role of small and medium practices in providing business support to small- and medium-sized enterprises. (Project Report) New York, USA: International Federation of Accountants. 32 p. ISBN 9781608150649. Retrieved from: http://www.ifac.org

Bolton, D. L., \& Lane, M. D. (2012). Individual entrepreneurial orientation: development of a measurement instrument. Education and Training, 54 (23), 219-233.

Bouri, A., Breij, M., Diop, M., Kempner, R., Klinger, B., \& Stevenson, K. (2011). Report on Support to SMEs in Developing Countries Through Financial Intermediaries, Retrieved from Wouter.Deelder@dalberg.com.

Bureau of Labor Statistics. (2018). Survival of private sector establishments by opening year. Retrieved from: https://www.bls.gov/bdm/us_age_naics_00_table7.txt

BusinessTech. (2018, July 25). The alarming truth about the number of small businesses in South Africa. Retrieved from:

https://businesstech.co.za/news/business/260797/the-alarming-truth-about-thenumber-of-small-businesses-in-south-africa/

Butler, A., \& Cornaggia, J. (2009). Does access to external finance improve productivity? Evidence from a natural experiment. Journal of Financial Economics, 99 (1), 184-203.

Chang, C. L. (2015). Entrepreneurial orientation, communication strategies, and new product success: a theoretic model. Academy of Strategic Management Journal, 14 (1), 1-19.

Chang, S. C., Lin, R. J., Chang, F. J., \& Chen, R. H. (2007). Achieving manufacturing flexibility through entrepreneurial orientation. Industrial Management \& Data Systems, 107 (7), 997-1017.

Cheng, B., loannou, I., \& Serafeim, G. (2014). Corporate social responsibility and access to finance. Strategic Management Journal, 35 (1), 1-23.

Churchill, N. C., \& Lewis, V. L. (1987). The five stages of small business growth. Harvard business review, 3 (3). Retrieved from: https://hbr.org/1983/05/the-five-stages-ofsmall-business-growth

Covin, G., \& Slevin, D. (1989). Strategic management of small firms in hostile and benign environments. Strategic Management Journal, 10 (1), 75-87.

Covin, J. G., \& Lumpkin, G. T. (2011). Entrepreneurial orientation theory and research: Reflections on a needed construct. Entry Theory and Practice, 35(5), 855-872. 
Esteve, E. A., Peinoda, S. A., \& Peinado, S. E. (2009). The influence of top management teams in the strategic orientation and performance of Small and Medium-sized Enterprises. British Journal of Management, 20 (4), 581-559.

Fatoki, O. (2012). The Impact of Entrepreneurial Orientation on Access to Debt Finance and Performance of Small and Medium Enterprises in South Africa. Journal Social Science, 32(2), 121-131.

Frank, H., Kessler, A., \& Fink, M. (2010). Entrepreneurial Orientation and Business Performance - A Replication Study. Schmalenbach Business Review, 62, 175-198.

Fuentes-Fuentes, M. D. M., Bojica, A. M., \& Ruiz-Arroyo, M. (2015). Entrepreneurial orientation and knowledge acquisition: effects on performance in the specific context of women-owned firms. International Entrepreneurship Management Journal, 11 (2015), 695-717.

Gathenya, J. W., Bwisa, H. M., \& Kihoro, J. M. (2011). Interaction between women entrepreneurs' age and education on business dynamics in Small and Medium Enterprises in Kenya. International Journal of Business and Social Science, 2 (15), 265272.

Ghimire, B., \& Abo, R. (2013). An empirical investigation of Ivorian SMEs access to bank finance: Constraining factors at demand-level. Journal of Finance and Investment Analysis, 2 (4), 29-55.

Gill, A. \& Biger, N. (2012). Barriers to small business growth in Canada. Journal of Small Business and Enterprise Development, 19 (4), 656 - 668.

Hair, J. F., Black, W. C., Babin, B. J., \& Anderson, R. E., (2014). Multivariate data analysis (7 ${ }^{\text {th }}$ ed.). New Jersey: Pearson Prentice-Hall.

Hussain, J., Millman, C., \& Matlay, H. (2006). SME financing in the UK and in China: a comparative perspective. Journal of Small Business and Enterprise Development, 13 (4), 584-599.

Ibrahim, M. A., \& Mohdshariff, M. N. (2015). Mediating Role of Access to Finance on the Relationship between Strategic Orientation Attributes and Small Medium Enterprises (SMEs) Performance in Nigeria. Proceedings of 3rd International Conference on Rural Development and Entrepreneurship, (pp. 91-102).

Isern, J., Agbakoba, A., Flaming, M., Mantilla, J., Pellegrini, G., \& Tarazi, M. (2009). Access to Finance in Nigeria: Microfinance, Branchless Banking, and SME Finance. Washington. Retrieved from:

https://www.cgap.org/sites/default/files/CGAP-Access-to-Finance-in-NigeriaMicrofinance-Branchless-Banking-and-SME-Finance-Jan-2009.pdf

Khalil, H., Nejadhussein, S. \& Fazel, A. (2013). The influence of entrepreneurial orientation on innovative performance. Journal of Knowledge-based Innovation in China, 5 (3), 262278.

Kreiser, P. M., Marino, L. D. \& Weaver, K. M. (2002). Reassessing the environment-EO link: the impact of environmental hostility on the dimensions of entrepreneurial orientation. Academy of Management Proceedings, (pp.71-76).

Lan, Q., \& Wu, S. (2010). An empirical study of entrepreneurial orientation and degree of internationalization of small and medium-sized Chinese manufacturing enterprises. Journal of Chinese Entrepreneurship, 2 (1), 53-75. 
Leitch, C., Hill, F., \& Neergaard, H. (2010). Entrepreneurial and business growth and the quest for a 'comprehensive theory': tilting at windmills? Entrepreneurship Theory and Practice, 34 (2), 249-260.

Levie, J., \& Lichtenstein, B. (2010). A terminal assessment of stages theory: introducing a dynamic states approach to entrepreneurship. Entrepreneurship Theory and Practice, 34 (2), 317-350.

Lu, C. S., Lai, K. H., \& Cheng, T. C. E. (2006). Application of structural equation modeling to evaluate the intention of shippers to use Internet services in liner shipping. European Journal of Operational Research, 180 (2), 845-867.

Lumpkin, G. T., \& Dess, G. G. (1996). Clarifying the entrepreneurial orientation construct and linking it to performance. The Academy of Management Review, 21 (1), 135-172.

Mason, M. C., Floreani, J., Miani, S., Beltrame, F., \& Cappelletto, R. (2015). Understanding the impact of entrepreneurial orientation on SMEs' performance: the role of the financing structure. Procedia Economics and Finance, 23, 1649-1661.

Messeghem, K. (2003). Strategic entrepreneurship and managerial activities in SME. International Small Business, 21 (2), 197-212.

Miles P. M., Arnold, R. D., \& Thompson D. L. (2010). The interrelationship between Environmental Hostility and Entrepreneurial Orientation, Journal of Applied Business Research, 9 (4), 12-23.

Miller, D. (1983). The correlates of entrepreneurship in three types of firms. Management science, 29 (7), 770-791.

Mohammed, U. D., \& Obeleagu-nzelibe, C. G. (2014). Entrepreneurial skills and profitability of Small and Medium Enterprises (SMEs): Resource acquisition strategies for new ventures in Nigeria. In $25^{\text {th }}$ International Business Research Conference (pp. 1-21). Cape Town.

Moreno, A., \& Casillas, J. (2008). Entrepreneurial orientation and growth of SMEs: a causal model. Entrepreneurship Theory and Practice, 32 (3), 507-528.

Morris, M. H., Lewis, P. S., \& Sexton, D. L. (1994). Re-conceptualizing entrepreneurship: an input-output perspective. SAM Advanced Management Journal, 59 (1), 21-31.

Mueller, R. O., \& Hancock, G. R. (2010). Structural Equating Modeling white book. Retrieved from: www.education.umd.edu/EDMS/fac/Hancock/SEM2page.html

Myers, S. C., \& Majluf, N. S. (1984). Corporate financing and investment decisions when firms have information that investors do not have. Journal of Financial Economics, 13 (2), 187-221. doi:10.1016/0304-405X(84)90023-0.

Nassif, V. M. J., Ghobril, A. N., \& Silva, N. S. (2010). Understanding the Entrepreneurial Process: A Dynamic Approach. Brazilian Administration Review, 7 (2), 213-226.

Newbert, S. L. (2014). Assessing performance measurement in RBV research. Journal of Strategy and Management, 7 (3), 265-283.

Ogunsiji, P. A. S., \& Ladanu, W. K. (2010). Entrepreneurial Orientation as a Panacea for the Ebbing Productivity in Nigerian Small and Medium Enterprises: A Theoretical Perspective. International Business Research, 3 (4), 192 -199.

Pandula, G. (2011). An empirical investigation of small and medium enterprises' access to bank finance: The case of an emerging economy. In Proceedings of ASBBS Annual Conference, (pp.18).

Prajogo, D. I. (2007). The relationship between competitive strategies and product quality. Industrial Management \& Data System, 107 (1), 69-83. 
Preda, G. (2013). The influence of entrepreneurial orientation and marketbased organizational learning on the firm's strategic innovation capability. Management \& Marketing Challenges for the Knowledge Society, 8 (4), 607-622.

Rauch, A., \& Frese, M. (2009). Psychological approaches to entrepreneurial success: a general model and an overview of findings, in Cooper, C.L. and Robertson, I.T. (Eds), International Review of Industrial and Organisational Psychology, Wiley, Chichester, 101-142.

Roxas, H. B. G. (2009). Institutions, Strategic Posture and the Performance of Micro, Small and Medium Enterprises, PhD Thesis, Victoria.University of Wellington, New Zealand.

Sekaran, U., \& Bougie, R. (2013). Research method for business: A skill building approaches ( $6^{\text {th }}$ ed.). United States: John Wiley \& Sons Inc.

SME Corporation Malaysia. (2019). Retrieved on August 11, 2019, from: http://www.smeinfo.com.my/index.php/en/sme-definition/developing-malaysiansmes/importance-of-smes

Smith, R. L., \& Smith, J. K. (2007). Entrepreneurial Finance ( $2^{\text {nd }}$ ed.). New York: John Wiley and Sons.

Stam, E., \& Garnsey, E. W. (2008). Entrepreneurship in the Knowledge Economy. Centre for Technology Management (CTM) Working Paper, No. 2007/04. Retrieved from: http://dx.doi.org/10.2139/ssrn.1923098

Teece, D. (1982). Towards an economic theory of the multiproduct firm. Journal of Economic Behavior and Organization, 3 (1), 39-63.

The World Bank. (2019). Retrieved from http://www.worldbank.org/en/topic/jobsanddevelopment/overview

Verwaal, E., Bruining, H., Wright, M., Manigart, S., \& Lockett, A. (2010). Resources access needs and capabilities as mediators of the relationship between VC firm size and syndication. Small Business Economics, 4 (1), 277-291.

Walter, A., Auer, M., \& Ritter, T. (2006). The impact of network capabilities and entrepreneurial orientation on university spin-off performance. Journal of Business Venturing, 21, 541-567.

Wei-Loon, K. (2013). Entrepreneurial Orientation (EO) and Performance of GovernmentLinked Companies (GLCs). Journal of Entrepreneurship Management and Innovation (JEMI), 9 (3), 21- 41.

Wernerfelt, B. (1984). A resource-based view of the firm. Strategic Management Journal, 5 (2), 171-180.

Wiklund, J., \& Shepherd, D. (2005). Entrepreneurial orientation and small business performance: a configurational approach. Journal of Business Venturing. 20(1), 71-89.

Xavier, S. R., Kelley, D., Herrington, M., \& Vorderwulbecke, A., (2013). Global Entrepreneurship Monitor (GEM) 2012 Global Report.

Zainudin, A. (2015). SEM Made Simple: A gentle approach to learning structural equation modeling. Bangi, Selangor: MPWS Rich Publication.

Zampetakis, L. A., Vekini, M., \& Moustakis, V. (2011). Entrepreneurial orientation, access to financial resources, and product performance in the Greek commercial TV industry, The Service Industries Journal, 31 (6), 897-910.

Zhang, M. (2013, July 31). Half of Chinese businesses fail within five years. China.org.cn. Retrieved from:

http://www.china.org.cn/business/2013-7/31/content_29583871.html 